\title{
Mesothelin-specific Chimeric Antigen Receptor-engineered Peripheral Blood Lymphocytes
}

National Cancer Institute

\section{Source}

National Cancer Institute. Mesothelin-specific Chimeric Antigen Receptor-engineered

Peripheral Blood Lymphocytes. NCI Thesaurus. Code C101773.

A preparation of peripheral blood lymphocytes (PBLs) transduced with a retroviral vector encoding a T cell chimeric antigen receptor (CAR) specific for mesothelin with potential immunostimulatory and antineoplastic activities. After transduction, expansion in culture, and reintroduction into the patient, the mesothelin-specific chimeric antigen receptorengineered PBLs bind to tumor cells expressing mesothelin. This may stimulate the secretion of cytokines and result in cell lysis of mesothelin-expressing cancer cells. Mesothelin, a cell surface glycoprotein involved in cell adhesion, is overexpressed in many epithelial-derived cancers. 